\title{
Justiciability and proceedings in the Oireachtas: the case of Angela Kerins
}

\section{Tom Hickey*}

This article considers Angela Kerins v John McGuinness, a 2019 case decided by the Irish Supreme Court concerning the justiciability of parliamentary proceedings. It is in four parts. The first two are descriptive: one presents the important facts of Kerins; the other, the relevant constitutional text and precedents. Part III assesses how, in light of the text and precedents, the judges approached the question of justiciability in the case. It gives some consideration to the approach taken to the same question in Denis O'Brien v Clerk of Dáil Eireann, a related case decided in the same period, and in tandem, by the same seven judges. The concluding part offers analysis of the coherence and implications of this jurisprudence.

\section{Angela Kerins and Denis O'Brien: the facts}

Angela Kerins was the CEO of Rehab, a private charity that carries out healthcare-related work for which it received around $€ 80$ million annually in public funding. Following media attention on the issue of executive pay in the charity sector, including on her own, Kerins was invited by the chair of the Public Accounts Committee (PAC) of Dáil Éireann to attend a hearing in February 2014. Although not under a legal obligation to do so, she took up the invitation. At the hearing she was subjected to what she later claimed was unfair treatment at the hands of committee members: the hearing lasted seven hours yet she only had one short break; members asked her questions about her pension arrangements and other significant matters despite her not having been given notice in the invitation that they would do so; she was told that she was "grossly overpaid;" that she applied "double standards" to the pay of Rehab staff as compared to her own; that she ran Rehab "like a personal fiefdom;" and so on. ${ }^{1}$

The evidence was that Ms Kerins was significantly traumatised as a result and that she attempted to take her own life a few weeks later, in March. ${ }^{2}$ She received further invitations to appear before PAC in April, which she declined. (In the event, despite her not being present at an April meeting, other Rehab employees were questioned extensively by parliamentarians about Kerins' salary and dealings as CEO: her name appears well over a hundred times on the transcript). ${ }^{3}$ PAC later applied under the relevant legislation to another Dáil Committee - the Committee on Procedure and Privileges (CPP) - to seek the power to compel her attendance. ${ }^{4}$ That was refused on the ground that, in the CPP's view, PAC, in

\footnotetext{
*Assistant Professor, School of Law and Government, Dublin City University.

${ }^{1}$ [2017] IEHC 377, at para 23.

2 [2017] IEHC 377, at para 23; [2019] IESC 11, at para 2.10.

3 The transcript is available at www.oireachtas.ie/en/debates/debate/committee_of_public_accounts/2014-04-10. See note 31 for my take on this meeting.

${ }^{4}$ Oireachtas (Inquiries, Privileges and Procedures) Act 2013.
} 
questioning her, would have been acting beyond its powers. ${ }^{5}$ PAC's pursuit of Angela Kerins petered out at that point.

Kerins later made an application before a Divisional High Court for a declaration that PAC's activities had been unlawful. She was unsuccessful. Kelly P explained that he understood the matter to be non-justiciable on the basis of the privileges and immunities conferred on the Houses of the Oireachtas under three provisions of Article 15 of the Constitution - 15.10, 15.12 and 15.13. The concluding lines of Kelly P's judgment read as follows:

For upwards of four centuries [referring to Article 9 of the English Bill of Rights, which he had described as "one of the forbears of Article 15"] it has been recognised in common law jurisdictions throughout the world that the courts exercise no function in relation to speech in parliament. This is fundamental to the separation of powers and is a cornerstone of constitutional democracy...If members of either House were constrained in their speech in the manner contended for by the applicant, the effective functioning of parliament would be impaired in a manner expressly forbidden in absolute terms by the Constitution. ${ }^{6}$

Kerins appealed this ruling to the Supreme Court. In its principal judgment handed down in February 2019, it overturned the decision of the Divisional Court, ruling that the parliamentarians' utterances were justiciable. ${ }^{7}$ The following May, having received further submissions on certain matters in the meantime, the Supreme Court followed up with a declaration that PAC had indeed acted unlawfully in its treatment of Angela Kerins. ${ }^{8}$

The Supreme Court's judgment in Denis O'Brien v Clerk of Dáil Éireann was handed down in March 2019, one week after the principal judgment in Kerins. ${ }^{9}$ Its facts recall an episode at Westminster in 2018 in which Lord Peter Hain used parliamentary privilege to name a businessperson who had been the subject of serious allegations in the Daily Telegraph, that businessperson having earlier obtained a temporary injunction against the newspaper preventing it from disclosing his identity. ${ }^{10}$ O'Brien, in 2015 , had obtained a temporary injunction restraining various broadcasters from publicising information concerning particular banking arrangements that he had allegedly agreed with the Irish Bank Resolution Corporation. Shortly afterwards, two TDs made a series of statements on the floor of Dáil

\footnotetext{
${ }^{5}$ In short, because Rehab was not a public body.

${ }^{6}$ [2017] IEHC 377, at para 111-113 (emphasis added).

${ }^{7}$ [2019] IESC 11.

8 [2019] IESC 42.

${ }^{9}$ [2019] IESC 12.

${ }^{10}$ For analysis, see Graeme Watt, "Proceedings in Parliament" (2019) Public Law 469-475.
} 
Éireann revealing much of that very information. O'Brien later brought the action: He sought various declarations including that the statements had been designed to frustrate court orders and had breached his personal rights. His lawyers made what the High Court judge described as a "tactical decision" to take the action against actors other than the TDs who made the statements. ${ }^{11}$ Instead, it was brought against the Clerk of Dáil Éireann and members of the CPP who, following complaints made on behalf of O'Brien, had ruled that the TDs had not abused parliamentary privilege. ${ }^{12}$ These tactics were apparently aimed at eluding the obstacles contained in Article 15 pertaining to the justiciability of parliamentary utterances. O'Brien's claim failed at the High Court on the justiciability ground. This time the Supreme Court upheld the lower court's decision.

\section{The constitutional framework and key precedents}

Article 15 of the Irish Constitution addresses the constitution and powers of a bicameral national parliament, the Oireachtas. Article 15.10 refers to each House having power to "ensure freedom of debate" and to "attach penalties" for the infringement of “...its own rules and standing orders..." Article 15.12 provides that "...utterances made in either House wherever published shall be privileged." Under Article 15.13 the members of each House "shall not, in respect of any utterance in either House, be amenable to any court or any authority other than the House itself." The provenance of these provisions in early modern English law is not difficult to discern. We see modifications in there of phrases from at least three different laws enacted in the $17^{\text {th }}$ century. ${ }^{13}$ This might in part explain their lack of clarity: For provisions of a codified constitution that pertain to relatively specific matters (relative to matters engaged by conventional rights provisions, for instance), so many questions are left so open. Does the phrase "privileged" in Article 15.12 mean that the courts can have no cognisance, whatever the context, of utterances made in the Houses, for instance? What are we to make of the lack of an express ouster clause in Article 15.10? And so on. ${ }^{14}$

By the time it came to deciding Kerins and O'Brien, a body of caselaw had shed some light, including by establishing clear differences in the Irish constitutional position to that in the UK. Three cases in particular informed the approaches taken by the Supreme Court in 2019: In re Haughey (1971), ${ }^{15}$ Abbeylara (2002), ${ }^{16}$ and Callely $v$ Moylan $(2014) .{ }^{17}$ This is not the

\footnotetext{
${ }^{11}$ [2017] IEHC 377, at [103].

12 [2019] IESC 12, at [2.18].

${ }^{13}$ These are the Protestation of 1621, the Treason and Seditious Practices Act 1661, and the Bill of Rights. For the relevant phrases in those instruments, see Paul M Hunneyball, "The House of Commons, 1603-29" in Clyve Jones (ed.) A Short History of Parliament (London: The Boydell Press, 2009), pp. 100-109.

${ }^{14}$ For a lengthier list, see Brian Murray, "Judicial Review of Parliamentary Proceedings and Procedures under the Irish Constitution," in Eoin Carolan and Oran Doyle (eds), The Irish Constitution: Governance and Values (Thomson Round Hall, 2009), 147-180, at 148.

${ }^{15}$ [1971] 1 IR 217.
} 
place to go through the trilogy in detail: for that, readers should look to other work. ${ }^{18}$ For now, the following overview should suffice to set up what is to follow:

- In each of the three, the applicant(s) had been compelled to attend particular Dáil or Seanad committee hearings under statutory powers enjoyed by the committees. (Recall that Kerins had taken up an invitation to attend).

- In each of the three, the committee engaged or proposed to engage in a process designed to make findings. (This was not the case in respect of Kerins).

- Although the court in each of the three cases considered certain parliamentary utterances, in none was any utterance central to any claim made. Rather, the courts did so for indirect reasons: e.g. in order to help characterise an action of, or a process adopted by, a committee. Two supplementary points on this: First, in In re Haughey - the origin of this species of Irish cases - the question of the authority of the Court to consider utterances, apparently not litigated, was simply assumed by the judges. ${ }^{19}$ Second, this distinction between direct and indirect consideration was not articulated in any of the judgments in the trilogy, but emerges forcefully in Kerins.

- In Haughey and Abbeylara, the applicants were not members of the Oireachtas: rather, a private citizen, and members of the Gardaí, respectively. In Callely, the applicant was a senator who had been found by a Seanad committee to have misrepresented his home address in expenses claims, and suspended without pay on foot of that finding.

- Haughey won his case in the Supreme Court. So too did the gardaí in Abbeylara, by a 5-2 majority. (Each of these wins was effectively against an Oireachtas committee). Senator Callely lost in what was ultimately a 4-3 decision - although there was a bamboozling series of splits on different issues in the case. ${ }^{20}$ The four comprising the majority on the ultimate outcome were each satisfied that the Seanad committee had not breached fair procedures in its handling of Callely.

\footnotetext{
${ }^{16}$ Maguire v Ardagh [2002] 1 IR 385, popularly known as Abbeylara.

${ }^{17}$ [2014] 4 IR 112.

${ }^{18}$ See Murray, note 14; Oran Doyle and Tom Hickey, Constitutional Law: Texts, Cases and Materials (Clarus Press, 2019), pp. 139-152; Gerard Hogan, Gerry Whyte, David Kenny and Rachael Walsh, Kelly: The Irish Constitution ( $5^{\text {th }}$ ed, Bloomsbury Professional, Dublin, 2018), at check page numbers.

${ }^{19}$ See Murray, note 14, at 163-164.

${ }^{20}$ For the clearest account of how, see Hogan et al, note 18, at p 356, particularly footnotes 388 and 389.
} 
- For present purposes, the interesting split in Callely was that on justiciability, broadly conceived (for a technical reason there was a different split on justiciability in the circumstances of the case, i.e. justiciability, narrowly conceived). This split was diametric: O'Donnell and Clarke JJ, who wrote a joint judgment, formed part of the majority of four on both the outcome and on this issue. They were still on the Court when it decided Kerins. So too was McKechnie J, who was in dissent on the outcome and also on this issue. On justiciability, his disagreement with O'Donnell and Clarke JJ could hardly have been more forcefully articulated in Callely. Yet in Kerins and O'Brien, all three came to agree. (Clarke had in the meantime been appointed chief justice. He wrote a judgment on behalf of all seven judges in each of the two 2019 cases).

To elaborate just a little on this last point, McKechnie $\mathrm{J}$ cast aside any pretension at passive virtues in his dealing with justiciability in 2014. He expressed bemusement at the notion that the courts "could not...exercise the very functions for which [they] exist, namely, in a case such as this, the vindication of [Senator Callely's] core constitutional rights..."21

In their joint judgment, O'Donnell and Clarke JJ, by way of justifying their contrary conclusion, articulated an elaborate purposive interpretation of the constitutional text, supplementing it with Canadian and UK constitutional comparisons. Presaging the Kelly P's judgment for the Divisional Court's position in Kerins, they associate parliamentary immunity with "the autonomy of parliament," where autonomy is understood as "conferred on Parliamentarians [not] merely as a sign of respect but because such autonomy from outsiders is necessary to enable Parliament and its members to get their job done." ${ }^{22}$ The Irish framework, they said, had the same underlying policy as Article 9 of the Bill of Rights: to secure the "freedom of parliament from intimidation or even influence by...the King, the King's court; the mob; the press; or any other agency which might interfere with the untrammeled discourse of public representatives..."23 All of this chimed with the their articulation of the range of application of the "privilege" in Article 15.12: it went beyond mere protection of parliamentarians against defamation suits; rather, it "means privilege from any legal proceedings. ${ }^{24}$

\section{Justiciability in Kerins (and $\left.O^{\prime} B r i e n\right)$}

\footnotetext{
${ }^{21}$ [2014] 4 IR 112, at 212.

${ }^{22} \mathrm{Ibid}$, at 178, quoting Binnie J in Canada (House of Commons) v Vaid [2005] 1 S.C.R. 667, at para 29.7.

${ }^{23}$ [2014] 4 IR 112, at 178-79, quoting David Gwynn Morgan, The Separation of Powers in the Irish Constitution (Dublin: Round Hall, 1997) at 222-223.

${ }^{24}$ [2014] 4 IR 112, at 181 (emphasis added).
} 
Half a decade later, in his judgment on behalf of all seven judges in Kerins, Clarke CJ assessed justiciability with reference to two pillars:

a) the protections afforded to utterances under Articles 15.12 and 15.13, and

b) the separation of powers norm more generally.

Before I assess it here under corresponding sub-headings, consider an unarticulated yet critical feature of the Court's approach to the nature of Angela Kerins' grievance. Whereas the Divisional Court had understood it as rooted in those things that were uttered to and about her in that PAC hearing and thus as non-justiciable under the first pillar, the Supreme Court saw it as arising partially from those utterances, but as grounded fundamentally in what Clarke CJ described as an "action" of the committee as a collective whole, where that action consisted in "inviting her to attend the hearing on a particular basis and then 'acting significantly outside of the terms of the invitation once she attended." ${ }^{25}$ I suggest that this, in practical terms, was the most decisive move made by the judges. It had the effect of abstracting away from the utterances thereby rendering possible what had looked impossible: that Kerins might elude the protections afforded to parliamentary utterances under the first pillar of non-justiciability.

a) the first pillar: the protections of utterances in Articles 15.12 and 15.13

What then of the articulated reasons as to why Angela Kerins managed to get around the express constitutional immunities? Clarke CJ adopted a more forensic approach to the meaning of the phrases than had the judges on the Divisional Court or, indeed had judges (including himself) in earlier cases. Rather than blocking consideration of the matter outright, the Article 15 privileges and immunities were presented as relevant to two quite specific questions. First - recalling the third of the bullet-points on the trilogy of precedents - whether the sub-articles might prevent a court from considering evidence of what had transpired the Oireachtas entirely, i.e. even for a limited purpose such as characterising an "action" of a committee ${ }^{26}$ Second, whether the sub-articles might prevent a court from determining that a given action of a House or a committee was unlawful, i.e. as distinct from making any finding directed against any parliamentarian for what she said in parliament?

The Court's answers conflict sharply with the Divisional Court ruling: they could be expressed, respectively, as "Absolutely not" and "Not absolutely". These answers had much to do with the Court's reading of the elements of the trilogy addressed in the first and second

\footnotetext{
${ }^{25}$ [2019] IESC 11, at para 13.4.

${ }^{26} \mathrm{Ibid}$, at paras 8.1-8.17.
} 
bullet points. Recall that in each of those earlier cases the judges reviewed what had transpired at an Oireachtas committee. If so, why not in Kerins? One argument as to why not - a compelling one in my view - is that the protagonists in the earlier cases had been before a parliamentary committee on pain of criminal sanction: the committees in question had successfully deployed their statutory power to compel attendance. This might have been thought the key that unlocked a door that otherwise would have remained shut. (Or, drawing in the second bullet point, the combination of this and the fact that those committees had been tasked with making formal findings, i.e. they were adjudicatory in a way that PAC, in the Kerins' episode, was not).

Such a reading would have had much to commend it as a matter of constitutional principle, the powers to coerce, to adjudicate and to impose penalty being so intimately associated with the judicial function. The reliance of those earlier committees on statutory powers, given the entrenchment of judicial review of legislation in the Irish system, similarly tended towards allowing for review of the exercise by those committees of those powers. And it would have been to recognise an intuitively significant distinction: The applicants in the earlier cases were in serious peril which, but for the courts, they could never have avoided (Haughey faced a six-month jail sentence!) whereas Kerins, though treated very badly, had gone along voluntarily. ${ }^{27}$ It would have appealed on the ground of consistency too: Where the justiciability issue was most directly considered in the earlier judgments the dicta emphasise the coercive and adjudicatory elements to a point suggesting them as critical - perhaps decisive - in each instance. ${ }^{28}$

In the event, the judges resisted the opportunity in Kerins to latch onto this as a norm distinguishing legitimate from illegitimate judicial intervention. Instead they emphasised the fact that their predecessors, in those earlier cases, had not restricted themselves to reviewing the lawfulness of the exercise by the Oireachtas of its statutory power of compellability. They had gone further, probing the underlying lawfulness of the business of a committee (Abbeylara), and of the procedures it followed (Callely) or intended to follow (Haughey). ${ }^{29}$ There is a chain of reasoning here, certainly. However, as Brian Murray has suggested, the significance of the fact of coercive power must go beyond whether it is resorted to or challenged in a given case. ${ }^{30}$ A process involving coercive power is fundamentally different,

\footnotetext{
${ }^{27}$ For why Haughey faced jail, see Doyle and Hickey, note 18, at 142.

${ }^{28}$ See for example Murray J's comments in Abbeylara, [2002] 1 IR 385, at 592, and Keane CJ's at 537-538. See also McGuinness J's comments in Abbeylara, and McKechnie, Hardiman and Murray JJ's in Callely. On this, see Brian Murray's article on Kerins and O'Brien, forthcoming in the Irish Supreme Court Review (on file with author).

${ }^{29}$ [2019] IESC 11, at para 9.4.

${ }^{30}$ See Murray, note 28 .
} 
in terms of its status and effect, from one that does not. Accordingly, I cannot but see the Court's reading of these features as having been informed by a wish to fashion a means of finding in favour of a citizen who had been treated appallingly. ${ }^{31}$

Having considered it elsewhere, I do little more than mention another of the reasons for these answers in respect of the first pillar: Clarke CJ's qualification of the use of the Westminster comparison. ${ }^{32}$ Though recognising that the drafters had looked to Westminster, and that reference to UK norms might accordingly be helpful to Irish judges, Clarke CJ deemed the Irish constitutional infrastructure distinct to the extent that, if there were to be an absolute barrier to judicial intervention, "it is not to be determined by lazy analogy with current or historic practice in the United Kingdom [but rather...] from what is to be deduced from the text and structure of the Irish Constitution." ${ }^{33}$ This might be thought a mild development of Irish constitutional doctrine on the point, but it conflicts sharply with the Divisional Court's reasoning (as can be gleaned from the excerpt in Section I) and is in a certain tension with much judicial dicta, including O'Donnell and Clarke JJ's own in Callely. ${ }^{34}$

Finally, the judges identified an interpretation of the phrases pertaining to utterances in Articles 15.12 and 15.13 that was sufficiently narrow to allow Kerins slip through. Whereas in Callely, as we saw, O'Donnell and Clarke JJ understood them to mean privilege "from any legal proceedings," in Kerins, the inclusion of the phrase "wherever published" in the first of the sub-articles is taken to suggest that it is a (specifically) reporting-oriented form of privilege with which the constitutional protections are "at least principally" concerned. ${ }^{35}$

Before moving to the second pillar, it bears emphasis that this interpretation came with what might be dubbed a Denis O'Brien-inspired twist. Clarke CJ insists that it would be impermissible to ask a court to intervene in a way which would "by necessary implication, require the Court to at least indirectly make a member amenable for breach of a privilege conferred on a member." ${ }^{36}$ Thus, he reasoned, "there is a clear area of non-justiciability which surrounds utterances made in the Houses or their committees or matters which are sufficiently closely connected to such utterances as to enjoy the same privileges and

\footnotetext{
${ }^{31}$ My sense is that the April meeting, at which Kerins was not present to defend herself, was critical to the outcome. For reasons that should be obvious, the judgment avoids direct reference to this meeting, or indeed to any particular utterance. I therefore cannot point to anything in it to support my suggestion. I do know that this meeting featured extensively in the submissions made to the Court. And the transcript (See note 3) reflects badly on three parliamentarians in particular, including the chairperson.

${ }^{32}$ See Doyle and Hickey, note 18 , at p $155, \mathrm{p} 158$.

33 [2019] IESC 11, at para 8.22.

${ }^{34}$ See for example Finlay CJ's dicta in Attorney General v Hamilton (No 2) 3 IR 227, at 270.

${ }^{35}$ This has echoes of Lord Browne-Wilkinson's comments in Pepper v Hart [1993] AC 593, at 683.

${ }^{36}$ [2019] IESC 11, at para 9.21.
} 
immunities." ${ }^{37}$ It was on this very basis that Denis O’Brien's "tactical decision" failed before the same judges the following week. If the judges were to engage in review of the CPP's decision regarding his complaints, they would be "indirectly or collaterally (and, therefore, impermissibly) considering the appropriateness or otherwise of utterances made in the Houses." 38

This twist in Kerins might be thought an important rowing back on the narrowing of the scope of the privileges in Article 15. Consider, however, Clarke CJ's words that I have italicised in the preceding paragraph. They recall the point made at the beginning of this section concerning the unarticulated but critical move made in respect of how the Supreme Court conceived Kerins' grievance. How, we must ask, was this twist not thought fatal to Kerins' claim itself!

b) the second pillar: the separation of powers

Having decided that the first pillar did not block Kerins's claim, the Supreme Court appears to decide the justiciability question - and, now that the coercive power point had been deemed incidental rather than decisive, to articulate a new theory of justiciability as it pertains to proceedings of the Oireachtas - with reference to the second. ${ }^{39}$ The framework he provides is vague (unavoidably, and appropriately). It would be inappropriate for courts to intervene, he says, "where that which was alleged could be described as technical, insufficiently serious or closely aligned to those areas (such as utterances within the Houses) which are given express constitutional immunity." ${ }^{, 40}$ The courts must also afford "a very significant margin of appreciation to the Houses as to the manner in which they conduct their business."

It is only in the Court's assessment of how the Kerins' episode fares by that framework that we get a sense of its potential application in future. In summary, the judges saw four factors, taken cumulatively, as carrying the episode over the line such that it was open to them to declare that PAC had acted unlawfully. Among these factors, the Court attached particular weight to the fact that the CPP, in its determination with respect to PAC's application to it to compel Angela Kerins to attend after she had rejected a follow-up invitation, had concluded that PAC would have been acting ultra vires. (See Section I). By implication, the reasoning goes, PAC had been so acting in the course of the January hearing, and the fact that a committee of the Oireachtas itself had so concluded was embraced by the judges as

\footnotetext{
${ }^{37}$ Ibid, at para 9.21 (italics added).

${ }^{38}$ Ibid, at para, at 9.10 .

${ }^{39}$ Ibid, at para 9.22 and para 9.25 .

${ }^{40} \mathrm{Ibid}$, at para 9.28-29 (brackets in original).
} 
supporting their authority, as judges, to make a finding of unlawfulness. ${ }^{41}$ It also attached weight to the lack of a remedy afforded to Angela Kerins by the Dáil subsequently. ${ }^{42}$

It might be thought that these (and the other two) factors were not so egregious, and accordingly that the new framework for assessment of justiciability is not likely to prove insurmountable for future litigants. However, having surely narrowed the scope of the first pillar, the judges appear keen to avoid doing the same with respect to this second, apparently based on things like their appreciation of its general importance in the constitutional order, and their concern for slippery slopes. Clarke CJ insists for example that it is was only their cumulative effect that took the episode over the line. ${ }^{43}$ Similarly, in the context of discussing the apparent deviation from the terms of the invitation (another of the four factors) he says that "it is no function of a court to entertain complaints which place reliance on what might be said to be a technical or minor deviation" but rather that the deviation must be "substantial and significant." 44

\section{Conclusion}

Writing about the UK Supreme Court judgment in Cherry/Miller (No 2), Mark Elliot noted the judges' willingness “to take a series of significant - but individually entirely legitimate legal steps...simultaneously, with the result that what appeared, following the Divisional Court's judgment, to be an utterly hopeless case culminated in a powerfully reasoned and unanimous Supreme Court judgment. ${ }^{45}$ I think the same might be said of Kerins. As in the prorogation case, the decisiveness of the Divisional Court's ruling on justiciability suggested Kerins had little chance in the Supreme Court. Like the Lady Hale/Lord Reed judgment, Clarke CJ's was both powerfully reasoned and unanimous. And like their UK counterparts, the Irish judges showed themselves prepared to take a series of significant legal steps simultaneously in reaching their conclusion on justiciability. If the Irish case fails to match Miller for overall significance, the steps taken by the Irish judges were greater in number and, if anything, involved greater dexterity: So many paragraphs in Clarke CJ's nearly 100-page judgment are devoted to developing some idea that might form part of the basis for establishing how, albeit by a fine margin, Kerins' claim evades a legal obstacle that would ordinarily prove fatal.

\footnotetext{
${ }^{41}$ Ibid, at para 10.8 .

${ }^{42}$ Ibid, at para 10.2 .

${ }^{43}$ [2019] IESC 11, at para 10.17.

$44 \mathrm{Ibid}$, at paras 10.12 and $11.2(\mathrm{~g})$.

${ }^{45}$ Mark Elliot, "The Supreme Court Judgment in Cherry/Miller (No. 2): A New Approach to Constitutional Adjudication?” Public Law for Everyone Blog, September 24, 2019.
} 
The fascinating juxtaposition of caution and boldness makes the Kerins judgment the most intellectually engaging handed down by the Irish Supreme Court in decades. There is much in it to woo judicial minimalists: no trace of the loose, lyrical and ill-judged assertions of constitutional principle so beloved of Walsh and Henchy JJ, those lionised figures of Ireland's activist era; ${ }^{46}$ every sinew strained to signal to parliamentarians the remaining robusteness of parliamentary immunity; ${ }^{47}$ that only the cumulative effect of various factors got it over the line, and more. Yet, when we consider the combination of...the centrality of parliamentary utterances to the claim; in that light, the express constitutional protections afforded to such utterances, and the shift made on their meaning by O'Donnell and Clarke JJ; the conspicuous absences in the episode: of compulsion; of any statutory dimension that might have invited or otherwise justified review; of a Haughey or Abbeylara-style adjducative element or of "findings" of any kind...it must count as a bold judgment. I take it to rival Abbeylara as the boldest of the Irish Court since Crotty [1987], that last and momentous sting of the Walsh/Henchy wasp. ${ }^{48}$

Did the judges get the right answer in Kerins? Respectfully, I say that I think not. Sure, the Haughey-Abbeylara-Callely trilogy had already broken much of the ground. And the Irish position on the question was not at one with that of the UK to begin with, given the entrenchment of judicial supremacy. The parliamentarians bullied Angela Kerins and breached her rights - not least in that follow-up meeting. ${ }^{49}$ And yes, the judgment's great naunce affords space to a future court to pivot to a position of deference. For all that, the dexterity required to identify an "action" distinguishable from the utterances in which that action consisted...tells its own story. It makes the nature of the grievance - its intimate and inescapable association with parliamentary utterances - enough on its own, in my view. If not, then its combination with those other factors makes Angela Kerins, for all its elegance, a judgment too far.

\footnotetext{
${ }^{46}$ Eg those made by Walsh J in McGee v Attorney General [1974] IR 284, at 310, 317-318; by Henchy J in Norris $v$ Attorney General [1984] IR 36, at 71.

${ }^{47}$ The most notable, in my view, is that set out in para 10.15 .

${ }^{48}$ Crotty v An Taoiseach [1987] IR 713.

${ }^{49}$ See note 31 .
} 